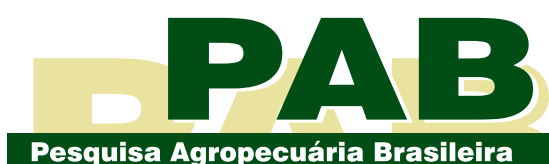

ISSN 1678-3921

Journal homepage: www.embrapa.br/pab

For manuscript submission and journal contents, access: www.scielo.br/pab

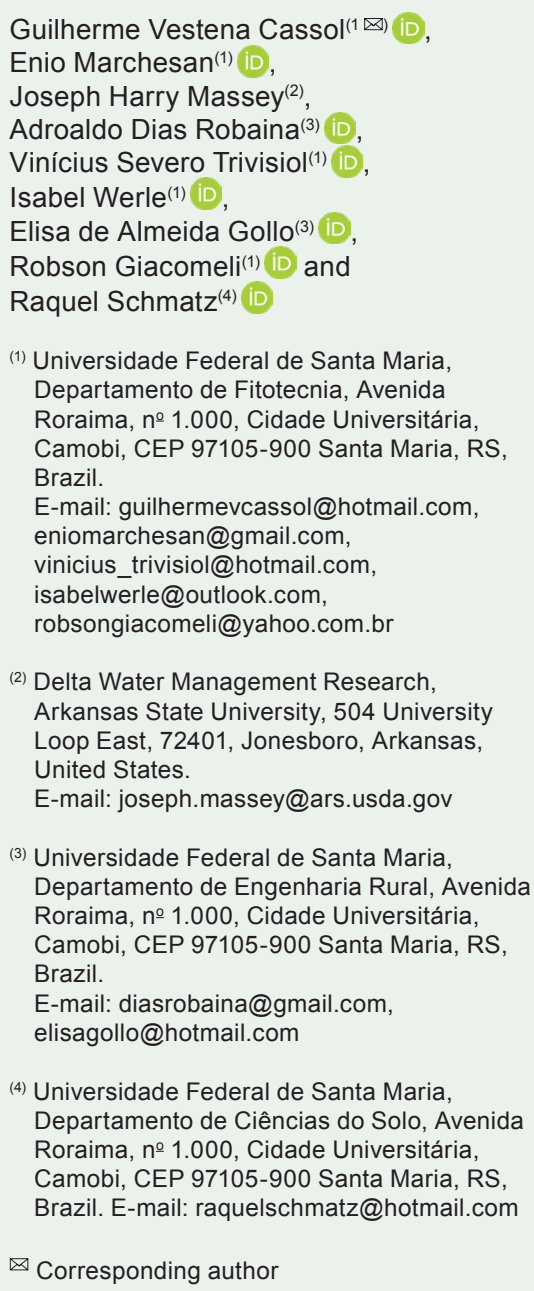

(4) Universidade Federal de Santa Maria, Departamento de Ciências do Solo, Avenida Roraima, no 1.000, Cidade Universitária, Camobi, CEP 97105-900 Santa Maria, RS, Brazil. E-mail: raquelschmatz@hotmail.com

$\bowtie$ Corresponding author

Received

April 07, 2019

Accepted

April 21, 2020

How to cite

CASSOL, G.V.; MARCHESAN, E.; MASSEY, J.H.; ROBAINA, A.D.; TRIVISIOL, V.S.; WERLE, I.; GOLLO, E. de A.; GIACOMELI, R; SCHMATZ, R. Raised seedbeds and irrigation increase the yield of soybean rotated with rice in lowland of Southern Brazil. Pesquisa Agropecuária Brasileira, v.55, e01398, 2020. DOI: https://doi.org/10.1590/S1678-3921. pab2020.v55.01398.

\section{Raised seedbeds and irrigation increase the yield of soybean rotated with rice in lowland of Southern Brazil}

\begin{abstract}
The objective of this work was to evaluate the effect of raised seedbeds associated with irrigation on the yield of soybean (Glycine max) rotated with rice (Oryza sativa) in lowland conditions in Southern Brazil. Field experiments were conducted in two crop seasons (2014/2015 and 2015/2016), with two planting systems (raised seedbed and flat planting) and two irrigation managements (irrigated and nonirrigated). Water use, biological nitrogen fixation, and yield were evaluated. The water used for raised seedbeds was $14 \%\left(151 \mathrm{~m}^{3} \mathrm{ha}^{-1}\right)$ and $27 \%\left(163 \mathrm{~m}^{3} \mathrm{ha}^{-1}\right)$ lower than that for flat planting in the first and second crop seasons, respectively. Irrigation increased nodule number per plant, nodule dry weight, and biological nitrogen fixation. The average grain yield of the raised seedbed system was $10 \%\left(529 \mathrm{~kg} \mathrm{ha}^{-1}\right)$ and $9 \%$ $\left(362 \mathrm{~kg} \mathrm{ha}^{-1}\right.$ ) higher than that of flat planting in 2014/2015 and 2015/2016, respectively. Irrigation improved yield by $5 \%\left(203 \mathrm{~kg} \mathrm{ha}^{-1}\right)$ and $7 \%\left(265 \mathrm{~kg} \mathrm{ha}^{-1}\right)$ in each crop year. The use of raised seedbeds associated with irrigation improves the yield of soybean grown in rotation with rice in lowland in Southern Brazil.
\end{abstract}

Index terms: Glycine max, Oryza sativa, cropping systems, crop rotation, water management.

\section{Camalhões e irrigação incrementam a produtividade de soja em rotação com arroz em terras baixas no Sul do Brasil}

Resumo - O objetivo deste trabalho foi avaliar o efeito do cultivo em camalhões associado à irrigação sobre a produtividade de soja (Glycine max) em rotação com arroz (Oryza sativa), em condições de terras baixas, no Sul do Brasil. Foram conduzidos experimentos em campo, em dois anos agrícolas (2014/2015 e 2015/2016), com dois sistemas de cultivo (camalhões e sem camalhões) e dois manejos de irrigação (irrigado e não irrigado). Foram avaliados uso de água, fixação biológica de nitrogênio e produtividade. O uso de água nos camalhões foi $14 \%\left(151 \mathrm{~m}^{3} \mathrm{ha}^{-1}\right)$ e $27 \%\left(163 \mathrm{~m}^{3} \mathrm{ha}^{-1}\right)$ menor que o no sistema sem camalhões, no primeiro e no segundo ano agrícola, respectivamente. A irrigação incrementou o número de nódulos por planta, a massa seca de nódulos e a fixação biológica de nitrogênio. A produtividade média no sistema com camalhões foi 10\% (529 $\left.\mathrm{kg} \mathrm{ha}^{-1}\right)$ e 9\% (362 $\left.\mathrm{kg} \mathrm{ha}^{-1}\right)$ maior que a no sistema sem camalhões em 2014/2015 e 2015/2016, respectivamente. A irrigação incrementou a produtividade em 5\% (203 kg ha-1) e 7\% (265 $\left.\mathrm{kg} \mathrm{ha}^{-1}\right)$ em cada ano agrícola. O uso de camalhões associado à irrigação incrementa a produtividade de soja em rotação com arroz em terras baixas, no Sul do Brasil.

Termos para indexação: Glycine max, Oryza sativa, sistemas de cultivo, rotação de culturas, manejo de água. 


\section{Introduction}

The cultivation of soybean [Glycine $\max$ (L.) Merr.] in rotation with rice (Oryza sativa L.) is rapidly increasing in Southern Brazil. According to surveys conducted by Instituto Rio Grandense do Arroz (IRGA, 2018), the soybean area rotated with rice increased from 11,000 ha in the 2009/2010 crop season to 280,000 ha in $2017 / 2018$. However, average soybean yields are relatively low, approximately 2,200 $\mathrm{kg} \mathrm{ha}^{-1}$, and generally do not surpass this value (IRGA, 2018). Other studies have reported yield potentials from 5,500 to $6,900 \mathrm{~kg} \mathrm{ha}^{-1}$, indicating that there are still challenges regarding the current farm practices (Zanon et al., 2016).

The stagnated yields in Brazil have been attributed to the traditional practice of growing soybean in flat-planted systems on Planossolos Háplicos, i.e., Albaqualfs, soils of lowland areas, common for rice production. These soils typically exhibit poor drainage, low hydraulic conductivity, low water holding capacity, and elevated soil bulk density that restrict internal oxygen transport and water movement into the soil profile (Gomes et al., 2006). Furthermore, the management practices particular to rice production have led to the formation of a traffic-induced hardpan 15 to $20 \mathrm{~cm}$ below the soil surface (Sartori et al., 2016). This increases both waterlogging in early soybean development and water stress later during reproduction, with concomitant effects on important physiological process such as photosynthesis and nitrogen fixation (Lanza et al., 2013; King et al., 2014). Therefore, need exists to devise improved practices to reduce water-related stresses and maximize the yields of soybean grown in rotation with rice in lowland areas of Southern Brazil.

Raised seedbeds have been reported to effectively mitigate the waterlogging of crops (Fiorin et al., 2009; Bruns \& Young, 2012; Ram et al., 2013) by lowering soil bulk density and increasing hydraulic conductivity and also runoff due to the presence of furrows (Bakker et al., 2005). This results improved soybean stand establishment and increased yields, when compared with flat planting (Bruns \& Young, 2012). Moreover, the furrows created between the beds facilitate irrigation, which can further improve yields, with positive economic net results, if properly managed (Bruns \& Young, 2012). In another study, furrow irrigation provided the highest grain yield and economic net return of soybean, in comparison with flood irrigation (Heatherly \& Spurlock, 2000).

However, in the rice producing areas of Southern Brazil, flood irrigation is still the common production system for flat-planted soybean (Sartori et al., 2015). The adoption of raised seedbeds could improve drainage and stand establishment, facilitating the adoption of furrow irrigation. In this context, research is needed to determine the combined potential benefits of associating raised beds with properly timed irrigation, considering the edaphic, climatic, and cultural conditions of that important crop region, where growers are more familiarized with rice than soybean production.

The objective of this work was to evaluate the effect of raised seedbeds associated with irrigation on the yield of soybean rotated with rice in lowland conditions in Southern Brazil.

\section{Materials and Methods}

A two-year field experiment was conducted during the 2014/2015 and 2015/2016 crop seasons at the crop science research station at Universidade Federal de Santa Maria, in the state of Rio Grande do Sul, Brazil $\left(29^{\circ} 43^{\prime} \mathrm{S}, 53^{\circ} 43^{\prime} \mathrm{W}\right.$, at $90 \mathrm{~m}$ of altitude). The soil there is classified as a Planossolo Háplico Eutrófico Arênico (Santos et al., 2018), i.e., an Albaqualf. The local climate is Cfa, subtropical humid, according to Köppen-Geiger's classification, adapted from Alvares et al. (2013), without a dry season and with the average temperature of the hottest month exceeding $22^{\circ} \mathrm{C}$. The experimental design for each crop season was a randomized complete block in a $2 \times 2$ factorial arrangement of treatments, with four replicates. The treatments consisted of a combination of two planting systems (raised seedbeds and flat planting) and two soybean irrigation managements (irrigated and nonirrigated) in $75-\mathrm{m}$ long and $3.0-\mathrm{m}$ wide plots; the treatments without irrigation were the controls. Fields were grown with rice over the past two seasons and disked after harvest in order to manage the rice straw.

Seedbeds were raised at the time of soybean planting using the Hyper Plus 6/5 A planter (Industrial KF, Cândido Godoi, RS, Brazil), developed to perform both planting and bedding operations simultaneously. Each raised seedbed was planted with two rows of soybean at a $0.5-\mathrm{m}$ row spacing. Average bed height and furrow 
spacing were 0.10 and $1.0 \mathrm{~m}$, respectively. The same planter was used for the flat-planting system, but with no hoppers attached. Soil berms were constructed around the irrigated plots to avoid irrigation leakage between irrigated and nonirrigated treatments, as well as to facilitate water flow in the flat-planted plots.

Seedbeds, in both crop seasons, were prepared between August and September using conventional tillage and precision leveling. The average field slope was approximately $0.03 \%$. Soybean was planted on $11 / 15 / 2014$ and 11/22/2015 using a seeding rate of 300,000 seeds per hectare. To determine growth habit, the Roundup Ready soybean variety Nidera 6209 of maturity group 6.0 was used. Seeds were treated with $250 \mathrm{~g} \mathrm{~L}^{-1}$ fipronil and $150 \mathrm{~g} \mathrm{~L}^{-1}+350 \mathrm{~g} \mathrm{~L}^{-1}$ carbendazin + thiram, using 150 and $200 \mathrm{~mL}$ per $100 \mathrm{~kg}$ seeds, respectively. The seeds were also inoculated with 100 g Bradyrhizobium japonicum per $50 \mathrm{~kg}$ seeds. Fertilization was performed simultaneously at planting, using the rates of $13 \mathrm{~kg} \mathrm{ha}^{-1}$ nitrogen, $55 \mathrm{~kg} \mathrm{ha}^{-1} \mathrm{P}_{2} \mathrm{O}_{5}$, and $87 \mathrm{~kg} \mathrm{ha}^{-1} \mathrm{~K}_{2} \mathrm{O}$. Weed and pest control followed the recommended practices for soybean production in Southern Brazil (Reunião..., 2012).

Water retention curves for the 0.00 to 0.10 and 0.10 to 0.20 - $\mathrm{m}$ depth layers were determined using the Richards pressure chamber method (Donagema et al., 2011). Soil samples from both cropping systems were taken 20 days after crop emergence to obtain soil bulk density using the core method (Donagema et al., 2011). Advance times and soil water infiltration rates for the raised seedbed and flat-planting systems were determined in order to properly manage surface irrigation in the watered plots. Rainfall was recorded using a conventional rain gauge placed in the middle of the experimental field.

Irrigation demand was determined by monitoring soil water content using CS616 frequency domain reflectometry (FDR) sensors, coupled to the CR1000 datalogger (Campbell Scientific Canada, Edmonton, Canada). In both cropping systems, the FDR sensors were placed horizontally at 0.05 and $0.15 \mathrm{~m}$ in the soil profile. Soil samples were taken weekly to determine gravimetric moisture content. The irrigation events were triggered when soil-water depletion in the 0.00 to $0.20-\mathrm{m}$ root zone exceeded $60 \%$ of the soil water content at field capacity (Bustomi Rosadi et al., 2005). The amount of water needed for each irrigation event was calculated taking into account the difference in soil moisture content the day before the event and the water needed to replace field capacity. Irrigation efficiency for both the raised seedbed and flat-planted systems was assumed to be $60 \%$.

Irrigation water was distributed across irrigated plots using plastic tubing with $38 \mathrm{~cm}$ of diameter $\mathrm{x}$ $254 \mu$ of thickness, with 7.6-cm plastic gates (Delta Plastics, Little Rock, AR, USA). The DN100 flow meter (Ciasey, São Paulo, SP, Brazil) was attached between the irrigation riser and the top part of the plastic tubing in order to record the volume of irrigation applied. For this purpose, each plot was irrigated individually.

At the end of each irrigation, water was held for 30 min inside the plots to allow infiltration in the soil. Afterwards, plots were drained and the runoff water was quantified using a cutthroat flume (Incontrol S/A, São Paulo, SP, Brazil) placed at the end of each individual plot.

Plant populations were recorded 20 days after crop emergence using a $1.0-\mathrm{m}$ quadrat and four replicates per plot. The number, viability, and dry weight of nodules per soybean plant and shoot dry matter were determined at the R5 growth stage (Fehr \& Caviness, 1977). For nodule evaluations, a $0.40-\mathrm{m}$ wide by $0.20-\mathrm{m}$ deep soil sample was collected from each plot using a shovel. After sampling, roots were manually washed in fresh water and taken to the laboratory. Nodule viability was determined according to the methodology proposed by Vieira Neto et al. (2008). After the viability measurements, the nodules were dried in a forced-air circulation oven, at $65^{\circ} \mathrm{C}$, to obtain the dry weight of nodules. Nitrogen fixation was estimated by the average relative abundance of ureide-N (Hungria \& Araujo, 1994). The ureide- $\mathrm{N}$ and nitrate content in the stems and leaves of the soybean plants were quantified in a laboratory, following recommended microbiological procedures (Hungria \& Araujo, 1994).

Grain yield was determined by hand harvesting a 10-m long and 2-m wide area within each soybean plot. Two subsamples were taken from each plot. After harvest, the samples were threshed, cleaned, and weighed. Moisture content was adjusted to $13 \%$. Irrigation water use efficiency $\left(\mathrm{I}_{\mathrm{WUE}}\right)$ was calculated as $\mathrm{I}_{\mathrm{WUE}}=[(\mathrm{Yi}-\mathrm{Yd}) / \mathrm{Ii}]$ where $\mathrm{Yi}$ is the yield of irrigation level i, Yd is the yield for the rainfed control plot, and Ii is the amount of irrigation applied for irrigation level I (Rhine et al., 2010).

Data were analyzed for independence, homogeneity, and normality and then subjected to the analysis of 
variance, at 5\% probability, using the general linear model procedure of the SAS software, version 9.3 (SAS Institute Inc., Cary, NC, USA). Cropping system, irrigation, and year were treated as fixed effects. As the interaction year by treatment was significant for most variables evaluated, data were analyzed separately by year. The relative abundance of ureide- $\mathrm{N}$ data was not transformed because nearly all values fell between the range of 50 and $90 \%$. Means of significant main effects were separated by Fischer's protected LSD test, at $5 \%$ probability.

\section{Results and Discussion}

The cropping systems did not affect soybean plant population in the 2014/2015 crop season, only in 2015/2016 (Table 1). Raised seedbeds increased by $25 \%$ the number of established plants, in comparison with flat planting at 20 days after crop emergence. The higher crop stand provided by the raised seedbed system in 2015/2016 was due to improved drainage, since rainfall events were intense from the Vc to V6 crop development stages (Figure 1). Raised beds help reduce stand losses early in the season when heavy rains can occur and standing water in the planted fields set up anaerobic conditions that kill germinating

Table 1. Soybean (Glycine max) plant population and shoot dry matter at the R5 growth stage as affected by cropping systems and irrigation in the 2014/2015 and 2015/2016 crop seasons.

\begin{tabular}{lcc}
\hline Cropping system & $\begin{array}{c}\text { Plant population } \\
\left.\text { (plants per } \mathrm{m}^{-2}\right)\end{array}$ & $\begin{array}{c}\text { Shoot dry matter } \\
(\mathrm{g} \text { per plant })\end{array}$ \\
\hline Raised seedbed & $2014 / 2015$ crop season \\
Flat planted & $28.7^{\mathrm{ns}}$ & $23.4^{\mathrm{ns}}$ \\
Irrigated & 27.5 & 24.4 \\
Nonirrigated & $28.3^{\mathrm{ns}}$ & $25.2^{\mathrm{ns}}$ \\
\hline CV $(\%)$ & 27.8 & 22.7 \\
\hline & 7.6 & 18.4 \\
Raised seedbed & $2015 / 2016$ crop season \\
Flat planted & $24.8^{*}$ & $25.2^{\mathrm{ns}}$ \\
Irrigated & 18.6 & 31.0 \\
Nonirrigated & $22.5^{\mathrm{ns}}$ & $28.6^{\mathrm{ns}}$ \\
\hline CV $(\%)$ & 21.0 & 27.4 \\
\hline
\end{tabular}

*Significant by Fischer's protected LSD test, at 5\% probability.

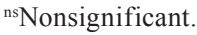

seeds. The furrows between beds enhance surface drainage and prevent stand losses by providing a more suitable rooting environment with increased $\mathrm{O}_{2}$ and $\mathrm{CO}_{2}$ gas exchange, necessary for germination and root metabolism (Bruns \& Young, 2012). In addition, raised seedbeds diminish the incidence of soil-borne diseases and prevent crop-stand losses by reducing periodic standing water in the field (Ram et al., 2013).

Rainfall was evenly distributed for the majority of the 2014/2015 and 2015/2016 crop seasons. Higher rainfall volumes occurred during the emergence and vegetative stages of soybean development in both study years (Figure 1). Therefore, there was no irrigation demand during these periods. However, rainfall and soil water content data showed that soybean needed irrigation during the R2 growth stage (full bloom), on $1 / 25 / 2015$, and the R3-R4 (pod touching) stage, on $2 / 5 / 2015$, in the $2014 / 2015$ season. The average soil water contents at $0.00-0.20 \mathrm{~m}$ in the first and second irrigation events were 52 and $48 \%$ of the established upper limit, respectively (Figure 2). In the 2015/2016
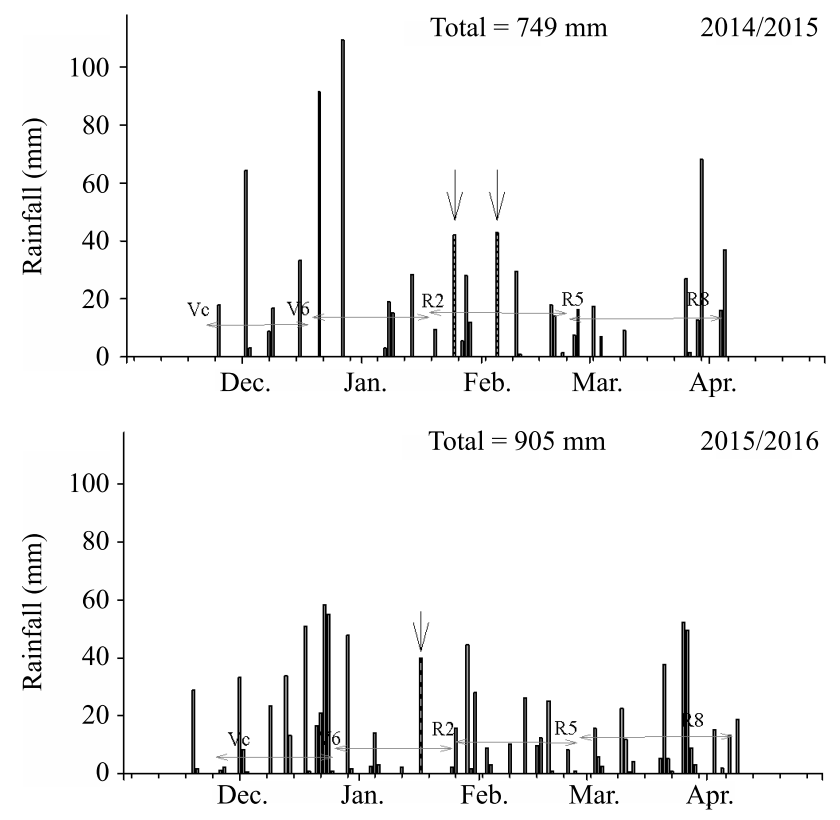

Figure 1. Seasonal rainfall (bars) and irrigation events (bars plus arrows) during the 2014/2015 and 2015/2016 crop seasons of soybean (Glycine max) rotated with rice (Oryza sativa). Grey lines represent the duration of the main soybean growth stages. Total rainfall represents accumulated rainfall between planting and harvest for each season. 
season, one irrigation event was performed during the R1-R2 growth stage (flowering to full bloom), on $1 / 15 / 2016$, when the average soil water content was at the 58\% upper limit at the $0.00-0.20$-m depth. By the soil water content analysis, even during years with a well-distributed rainfall, there was a need for irrigation at some phase of crop development. This was observed particularly when soybean plants reached the reproductive phase in which more water is required for transpiration and also for the compensation of losses caused by soil evaporation once dry matter accumulation increases (King et al., 2014). Moreover, soil water content dropped faster in the raised seedbed system at this stage. The drainage that helps mitigate standing water in the beginning of the crop season also contributed to reduce water content in the $0.00-0.20$-m soil layer later on. Therefore, irrigation might be a key component to prevent yield losses by water stress in the raised seedbed system.

The type of cropping system affected the volumes of irrigation applied. In 2014/2015, the raised seedbed system with furrow irrigation required, on average, $14 \%\left(151 \mathrm{~m}^{3} \mathrm{ha}^{-1}\right)$ less irrigation than flat planting with flood irrigation (Table 2). Water savings were even higher in 2015/2016, with the raised seedbed system requiring 27\% (163 $\left.\mathrm{m}^{3} \mathrm{ha}^{-1}\right)$ less total irrigation. However, no significant differences were observed in terms of irrigation water use efficiency across planting systems in the two crop seasons. Despite this, it has been reported that a lower volume of furrow
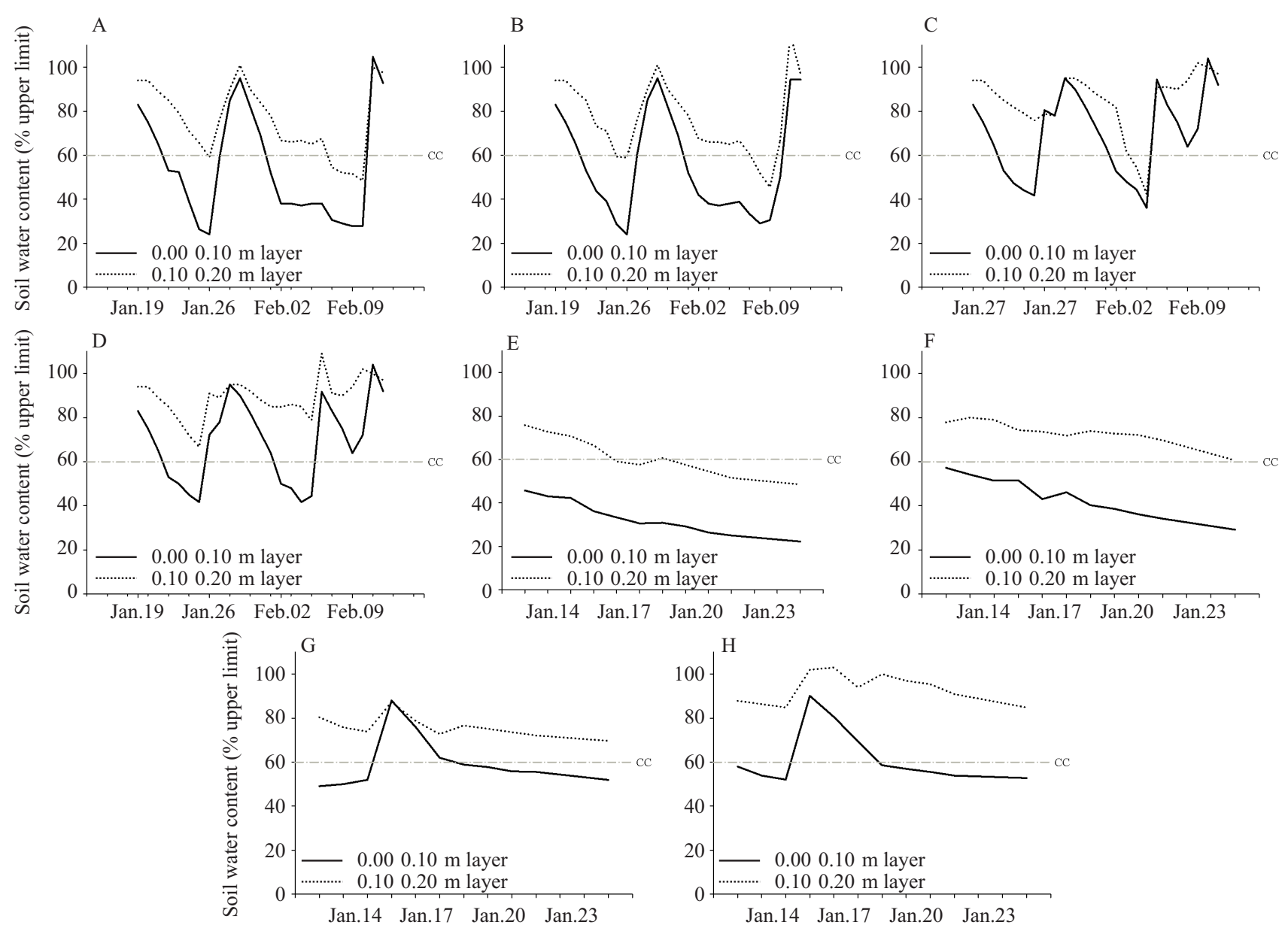

Figure 2. Soil water contents at the $0.00-0.10$ and $0.10-0.20-\mathrm{m}$ depths, respectively, in different soybean (Glycine max) planting systems: raised bed without irrigation (A and E), flat planting without irrigation (B and F), raised bed with furrow irrigation (C and G), and flat planting with flood irrigation (D and H), between irrigation events in the 2014/2015 (A, B, C, and D) and 2015/2016 (E, F, G, and H) crop seasons. The dashed line indicates the critical soil water content (CC) used to determine irrigation timings. 
irrigation reduces irrigated surface area, seepage, and deep percolation losses, when compared with flood irrigation (Heatherly \& Spurlock, 2000; Vories et al., 2002). The lower water requirement to irrigate soybean is an alternative for the irrigation of both rice and soybean simultaneously; otherwise, it may be needed to reduce the area planted with rice in order to increase the water available to irrigate soybean, since both crops share a similar irrigation infrastructure.

The number and viability of nodules were not affected by the cropping systems (Table 3). However, the dry weight of nodules was higher in the raised seedbed in 2015/2016. Irrigation increased the number of nodules per plant in 2014/2015 and the dry weight of nodules in 2015/2016 during the grain-filling period (R5). Besides increased numbers of nodules per plant, irrigation provided higher percentages for the relative abundance of ureide- $\mathrm{N}$ in both study years. The benefits of a properly managed irrigation for biological nitrogen fixation are related to the maintenance of the photosynthetic activity of soybean plants that is necessary for symbiotic processes (King et al., 2014). It has also been found that biological nitrogen fixation requires about $14 \%$ of the photoassimilates produced by soybean plants and that it is the physiological process

Table 2. Irrigation applied per each irrigation event, total irrigation applied, and irrigation water use efficiency $\left(\mathrm{I}_{\mathrm{WUE}}\right)$ for soybean (Glycine max) produced using the raisedseedbed and flat-planting systems during the 2014/2015 and 2015/2016 crop seasons.

\begin{tabular}{|c|c|c|c|c|}
\hline \multirow{2}{*}{$\begin{array}{l}\text { Cropping } \\
\text { system }\end{array}$} & \multicolumn{3}{|c|}{ Applied irrigation $\left(\mathrm{m}^{3} \mathrm{ha}^{-1}\right)$} & \multirow{2}{*}{$\begin{array}{l}\mathrm{I}_{(\mathrm{WUE})}{ }^{(1)} \\
\left(\mathrm{kg} \mathrm{m}^{-3}\right)\end{array}$} \\
\hline & $\begin{array}{c}1 / 5 / 2015 \text { or } \\
1 / 15 / 2016\end{array}$ & $2 / 5 / 2015$ & Total & \\
\hline & \multicolumn{4}{|c|}{ 2014/2015 crop season } \\
\hline Raised seedbed & $462 *$ & $471^{*}$ & $933^{*}$ & $0.25^{\mathrm{ns}}$ \\
\hline Flat planted & 520 & 564 & 1,084 & 0.20 \\
\hline Mean & 491 & 517 & 1,008 & 0.22 \\
\hline \multirow[t]{2}{*}{ CV $(\%)$} & 4.0 & 7.2 & 4.7 & 17.6 \\
\hline & \multicolumn{4}{|c|}{ 2015/2016 crop season } \\
\hline Raised seedbed & $436^{*}$ & - & $436^{*}$ & $0.48 \mathrm{~ns}$ \\
\hline Flat planted & 599 & - & 599 & 0.40 \\
\hline Mean & 517 & - & 517 & 0.44 \\
\hline CV $(\%)$ & 7.9 & - & 7.9 & 21.3 \\
\hline
\end{tabular}

(1) Obtained considering the total applied irrigation water and yield difference between irrigated and nonirrigated plots. *Significant by

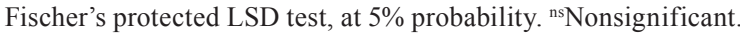

most sensitive to water stress (Salvagiotti et al., 2008; Mastrodomenico et al., 2013; Wingeyer et al., 2014).

Besides increasing nodulation, irrigation also increased the relative abundance of ureide-N. The ureides, allantoin and allantoic acid, are compounds primarily derived from biological nitrogen fixation in nodules that are exported to soybean shoots. The abundance of these compounds in soybean xylem sap or plant tissues has been directly related to the magnitude of biological nitrogen fixation and yield (Serraj et al., 1999; King et al., 2014). Therefore, irrigation is an essential management practice for maintaining nitrogen fixation and achieving high yields of soybean in rotation with rice.

Raised seedbeds and irrigation improved soybean yields in the 2014/2015 and 2015/2016 crop seasons (Table 4). Raised seedbeds provided approximately $10 \%\left(529 \mathrm{~kg} \mathrm{ha}^{-1}\right)$ and $9 \%\left(362 \mathrm{~kg} \mathrm{ha}^{-1}\right)$ increases in grain yield, compared with flat planting, in the first and second experimental years, respectively. The raised seedbed system helps to alleviate soil compaction, improving soybean root growth and plant development, which also increase crop tolerance to other potential abiotic stresses that may occur during the crop season (Sartori et al., 2015). Although raised seedbeds provide a better environment for root development, irrigation

Table 3. Number, viability, and dry weight of nodules and relative abundance of ureide-N per soybean (Glycine max) plant at the R5 growth stage, as affected by cropping system and irrigation in the 2014/2015 and 2015/2016 crop seasons.

\begin{tabular}{lcccc}
\hline $\begin{array}{l}\text { Cropping } \\
\text { system }\end{array}$ & $\begin{array}{c}\text { Nodules (no. } \\
\text { per plant) }\end{array}$ & $\begin{array}{c}\text { Viability } \\
(\%)\end{array}$ & $\begin{array}{c}\text { Dry weight } \\
\text { (g per plant) }\end{array}$ & $\begin{array}{c}\text { Ureide-N } \\
(\%)\end{array}$ \\
\hline Raised seedbed & $114^{\mathrm{ns}}$ & $\begin{array}{c}2014 / 2015 \text { crop season } \\
\text { ns }\end{array}$ & $0.94^{\mathrm{ns}}$ & $78.1^{\mathrm{ns}}$ \\
Flat planted & 105 & 86 & 0.88 & 77.3 \\
\hline Irrigated & $118^{*}$ & $84^{\mathrm{ns}}$ & $1.01^{\mathrm{ns}}$ & $78.7^{*}$ \\
Nonirrigated & 101 & 85 & 0.84 & 76.4 \\
\hline CV $(\%)$ & 11.2 & 8.8 & 25.2 & 2.9 \\
\hline & & $2015 / 2016$ crop season & \\
Raised seedbed & $66^{\mathrm{ns}}$ & $70^{\mathrm{ns}}$ & $0.63^{*}$ & $75.4^{\mathrm{ns}}$ \\
Flat planted & 67 & 64 & 0.53 & 75.1 \\
\hline Irrigated & $69^{\mathrm{ns}}$ & $70^{\mathrm{ns}}$ & $0.67^{*}$ & $78.2^{*}$ \\
Nonirrigated & 64 & 63 & 0.49 & 72.8 \\
\hline CV $(\%)$ & 18.9 & 17.7 & 4.1 & 4.6 \\
\hline
\end{tabular}

*Significant by Fischer's protected LSD test, at 5\% probability.

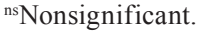


is essential to enhance crop growth, nodulation and nitrogen fixation, even during moderate water-deficit stress such as that observed in the two crop seasons. On average, irrigation increased grain yields by $5 \%$ $\left(203 \mathrm{~kg} \mathrm{ha}^{-1}\right)$ and $7 \%\left(265 \mathrm{~kg} \mathrm{ha}^{-1}\right)$ in comparison with the nonirrigated controls in 2014/2015 and 2015/2016, respectively. Yield gains due to irrigation were likely higher in the second study year when average soil water content dropped to $60 \%$ of the upper limit during eight consecutive days, compared with the six consecutive days in $2014 / 2015$. It should be noted that there was an average yield reduction of $33 \mathrm{~kg} \mathrm{ha}^{-1}$ for each day that soil water content dropped below $60 \%$ of the upper limit. Therefore, by maintaining soil water content above the threshold throughout the crop season, soybean nodulation, nitrogen fixation, and yield are consistently improved.

Raised seedbeds associated with irrigation mitigated crop stresses and increased the yields of soybean in lowland areas where poor drainage and soil compaction inhibit the growth and productivity of the species. The yields of soybean grown in the furrow-irrigated raised seedbeds were at least $15 \%$ higher than those of soybean subjected to nonirrigated flat planting over the two crop seasons. The obtained yield gains appear to result from improvements in crop growth and physiological processes such as enhanced crop establishment during wet years after soybean planting and enhanced activity of biological

Table 4. Grain yield of soybean (Glycine max) rotated with rice (Oryza sativa) as affected by cropping systems and irrigation during the 2014/2015 and 2015/2016 crop seasons.

\begin{tabular}{lccc}
\hline \multirow{2}{*}{$\begin{array}{l}\text { Cropping sys- } \\
\text { tem }\end{array}$} & \multicolumn{3}{c}{ Grain yield $\left(\mathrm{kg} \mathrm{ha}^{-1}\right)$} \\
\cline { 2 - 4 } & Irrigated & Nonirrigated & Mean \\
\hline \multirow{3}{*}{ Raised seedbed } & 4,618 & 4,382 & $4,500^{*}$ \\
Flat planted & 4,057 & 3,886 & 3,971 \\
\hline Mean & $4,337^{*}$ & 4,134 \\
CV (\%) & \multicolumn{3}{c}{4.5} \\
\hline & $2015 / 2016$ crop season \\
Raised seedbed & 4,028 & 3,849 & $3,938^{*}$ \\
Flat planted & 3,751 & 3,402 & 3,576 \\
\hline Mean & $3,890^{*}$ & 3,625 \\
CV (\%) & \multicolumn{3}{|}{5.5} \\
\hline
\end{tabular}

*Significant by Fischer's protected LSD test, at $5 \%$ probability. ${ }^{\mathrm{ns}}$ Nonsignificant. nitrogen fixation, as that observed in the ureide- $\mathrm{N}$ content of soybean plants. These findings highlight the potential of combining the management practices raised seedbeds and irrigation to maximize the yields of soybean grown in lowland areas of Southern Brazil.

\section{Conclusions}

1. Raised seedbeds associated with irrigation increase the grain yield of soybean (Glycine max), compared with flat planting without irrigation in lowland areas of Southern Brazil.

2. The combination of raised seedbeds and irrigation enhances crop establishment and biological nitrogen fixation, allowing producers to maximize the yields of soybean rotated with rice (Oryza sativa).

\section{Acknowledgments}

To Conselho Nacional de Desenvolvimento Científico e Tecnológico (CNPq), for financial support; and to Delta Plastics, for providing the irrigation materials needed for this study.

\section{References}

ALVARES, C.A.; STAPE, J.L.; SENTELHAS, P.C.; GONCALVES, J.L. de M. Modeling monthly mean air temperature for Brazil. Theoretical and Applied Climatology, v.113, p.407427, 2013. DOI: https://doi.org/10.1007/s00704-012-0796-6.

BAKKER, D.M.; HAMILTON, G.J.; HOULBROOKE, D.J.; SPANN, C. The effect of raised beds on soil structure, waterlogging, and productivity on duplex soils in Western Australia. Australian Journal of Soil Research, v.43, p.575-585, 2005. DOI: https://doi.org/10.1071/SR03118.

BRUNS, H.A.; YOUNG, L.D. Raised seedbeds for soybean in twin rows increase yields over flat seedbeds. Crop Management, v.11, p.1-7, 2012. DOI: https://doi.org/10.1094/CM-2012-0712-01-RS.

BUSTOMI ROSADI, R.A.; AFANDI; SENGE, M.; ITO, K.; ADOMAKO, J.T. Critical water content and water stress coefficient of soybean (Glycine max [L.] Merr.) under deficit irrigation. Paddy Water Environment, v.3, p.219-223, 2005. DOI: https://doi.org/10.1007/s10333-005-0017-3.

DONAGEMA, G.K.; CAMPOS, D.V.B. de; CALDERANO, S.B.; TEIXEIRA, W.G.; VIANA, J.H.M. (Org.). Manual de métodos de análise de solo. 2.ed. rev. Rio de Janeiro: Embrapa Solos, 2011. 230p. (Embrapa Solos. Documentos, 132). Available at: $<$ https:// www.embrapa.br/en/busca-de-publicacoes/-/publicacao/990374/ manual-de-metodos-de-analise-de-solo $>$. Accessed on: May 26 2020.

FEHR, W.R.; CAVINESS, C.E. Stages of soybean development. Ames: Iowa State University, 1977. 11p. (Special Report, 80). 
FIORIN, T.T.; SPOHR, R.B.; CARLESSO, R.; MICHELON, C.J.; DALlA SANTA, C.; DAVID, G. DE. Produção de silagem de milho sobre camalhões em solos de várzea. Pesquisa Aplicada \& Agrotecnologia, v.2, p.147-153, 2009.

GOMES, A. da S.; SILVA, C.A.S. da; PARFIT, J.M.B.; PAULETTO, E.A.; PINTO, L.F.S. Caracterização de indicadores da qualidade do solo, com ênfase às áreas de várzea do Rio Grande do Sul. Pelotas: Embrapa Clima Temperado, 2006. 41p. (Embrapa Clima Temperado. Documentos, 169).

HEATHERLY, L.G.; SPURLOCK, S.R. Furrow and flood irrigation of early-planted, early maturing soybean rotated with rice. Agronomy Journal, v.92, p.785-791, 2000. DOI: https://doi.org/10.2134/agronj2000.924785x.

HUNGRIA, M.; ARAUJO, R.S. (Ed.). Manual de métodos empregados em estudos de microbiologia agrícola. Brasília: Embrapa-SPI, 1994. 542p. (EMBRAPA-CNPAF. Documentos, 46). Available at: <https://www.embrapa.br/en/ busca-de-publicacoes/ /publicacao/199952/manual-de-metodosempregados-em-estudos-de-microbiologia-agricola $>$. Accessed on: May 262020.

IRGA. Instituto Riograndense do Arroz. Boletim de resultados da lavoura de arroz: safra 2017/18. Porto Alegre, 2018. 19p. Available at: <https://irga-admin.rs.gov.br/upload/ arquivos/201807/30100758-boletim-final-da-safra-201-18-final. pdf $>$. Accessed on: May 262020.

KING, C.A.; PURCELL, L.C.; BOLTON, A.; SPECH, J.E. A possible relationship between shoot $\mathrm{N}$ concentration and the sensitivity of $\mathrm{N}_{2}$ fixation to drought in soybean. Crop Science, v.54, p.746-756, 2014. DOI: https://doi.org/10.2135/ cropsci2013.04.0271.

LANZA, L.N.M.; ROSSI, S.C.; SODEK, L. Adubação nitrogenada beneficia soja alagada. Bragantia, v.72, p.2-9, 2013. DOI: https://doi.org/10.1590/S0006-87052013005000011.

MASTRODOMENICO, A.T.; PURCELL, L.C.; KING, C.C. The response and recovery of nitrogen fixation activity in soybean to water deficit at different reproductive developmental stages. Environmental and Experimental Botany, v.85, p.16-21, 2013. DOI: https://doi.org/10.1016/j.envexpbot.2012.07.006.

RAM, H.; SINGH, Y.; SAINI, K.S.; KLER, D.S.; TIMSINA, J. Tillage and planting methods effects on yield, water use efficiency and profitability of soybean-wheat system on a loamy sand soil. Experimental Agriculture, v.49, p.524-542, 2013. DOI: https://doi.org/10.1017/S0014479713000264.

REUNIÃO DE PESQUISA DE SOJA DA REGIÃO SUL, 39., 2012, Passo Fundo. Indicações técnicas para a cultura da soja no Rio Grande do Sul e em Santa Catarina, safras 2012/2013 e 2013/2014. Passo Fundo: Embrapa Trigo, 2012. 142p. (Embrapa Trigo. Documentos, 107). Organizadores: Leila Maria Costamilan, Mercedes Concórdia Carrão-Panizzi,
Mércio Luiz Strieder e Paulo Fernando Bertagnolli. Available at: $<$ https://ainfo.cnptia.embrapa.br/digital/bitstream/item/213046/1/ CNPT-ID-43975.pdf>. Accessed on: May 262020.

RHINE, M.D.; STEVENS, G.; SHANNON, G.; WRATHER, A.; SLEPER, D. Yield and nutritional responses to waterlogging of soybean cultivars. Irrigation Science, v.28, p.135-142, 2010. DOI: https://doi.org/10.1007/s00271-009-0168-x.

SALVAGIOTTI, F.; CASSMAN, K.G.; SPECHT, J.E.; WALTERS, D.T.; WEISS, A.; DOBERMANN, A. Nitrogen uptake, fixation and response to fertilizer $\mathrm{N}$ in soybeans: a review. Field Crops Research, v.108, p.1-13, 2008. DOI: https://doi.org/10.1016/j. fcr.2008.03.001.

SANTOS, H.G. dos; JACOMINE, P.K.T.; ANJOS, L.H.C. dos; OLIVEIRA, V.A. de; LUMBRERAS, J.F.; COELHO, M.R.; ALMEIDA, J.A. de; ARAUJO FILHO, J.C. de; OLIVEIRA, J.B. de; CUNHA, T.J.F. Sistema brasileiro de classificação de solos. 5.ed. rev. e ampl. Brasília: Embrapa, 2018. 356p.

SARTORI, G.M.S.; MARCHESAN, E.; DAVID, R. de; CARLESSO, R.; PETRY, M.T.; DONATO, G.; CARGNELUTTI FILHO, A.; SILVA, M.F. da. Rendimento de grãos de soja em função de sistemas de plantio e irrigação por superfície em Planossolos. Pesquisa Agropecuária Brasileira, v.50, p.1139-1149, 2015. DOI: https://doi.org/10.1590/S0100-204X2015001200003.

SARTORI, G.M.S.; MARCHESAN, E.; DAVID, R. de; DONATO, G.; COELHO, L.L.; AIRES, N.P.; ARAMBURU, B.B. Sistemas de preparo do solo e de semeadura no rendimento de grãos de soja em área de várzea. Ciência Rural, v.46, p.492-498, 2016. DOI: https://doi.org/10.1590/0103-8478cr20150676.

SERRAJ, R.; SINCLAIR, T.R.; PURCELL, L.C. Symbiotic $\mathrm{N}_{2}$ fixation response to drought. Journal of Experimental Botany, v.50, p.143-155, 1999. DOI: https://doi.org/10.1093/jxb/50.331.143.

VIEIRA NETO, S.A. PIRES, F.R.; MENEZES, C.C.E. de; MENEZES, J.F.S.; SILVA, A.G. da; SILVA, G.P.; ASSIS, R.L. de. Formas de aplicação de inoculante e seus efeitos sobre a nodulação da soja. Revista Brasileira de Ciência Solo, v.32, p.861-870, 2008.

VORIES, E.D.; COUNCE, P.A.; KEISLING, T.C. Comparison of flooded and furrow-irrigated rice on clay. Irrigation Science, v.21, p.139-144, 2002. DOI: https://doi.org/10.1007/s00271-002-0056-0.

WINGEYER, A.B.; ECHEVERRÍA, H.; SAINZ ROZAS, H. Growth and yield of irrigated and rainfed soybean with late nitrogen fertilization. Agronomy Journal, v.106, p.567-576, 2014. DOI: https://doi.org/10.2134/agronj2013.0255.

ZANON, A.J.; STRECK, N.A.; GRASSINI, P. Climate and management factors influence soybean yield potential in a subtropical environment. Agronomy Journal, v.108, p.1447-1454, 2016. DOI: https://doi.org/10.2134/agronj2015.0535. 